\title{
CROSS RIVER AS A MODEL FOR THE EVOLUTION OF BENUE-CONGO NOMINAL CLASS/CONCORD SYSTEMS
}

\author{
Nicholas Faraclas \\ University of California, Berkeley ${ }^{1}$
}

\begin{abstract}
Cross River languages exhibit nominal class/concord systems which typify almost every possible stage of simplification of the proto-Benue-Congo system, from full retention in some Upper Cross and Bendi languages to near complete elimination in the Ogoni group. The synchronic facts from Cross River shed light on some of the psycholinguistic processes involved in class/concord systems acquisition and retention as well as some of the sociolinguistic processes involved in the modification or loss of such systems. Taken together, the nominal class/concord systems of the Cross River languages correspond to points along a continuum or implicational scale which may prove to be of value in establishing a typology of class/concord systems throughout the Benue-Congo subbranch.
\end{abstract}

\section{Introduction}

1.1. Cross River languages and the Benue-Congo east-west interface. In light of recent work by the members of the Benue-Congo Working Group, it has been convincingly shown that a strict east-west division corresponding to Greenberg's Kwa-Benue-Congo divide is no longer justifiable. The results of careful examination and analysis of the data fully support the inclusion of the former Eastern Kwa languages in the Benue-Congo subbranch. The significance of this great step forward in Niger-Congo studies, however, should not lead us to overlook certain very general tendencies (perhaps areal characteristics) which serve to

${ }^{3}$ Special thanks are due to Prof. K. Williamson, whose forthcoming article entitled "How to become a Kwa language" served both as an inspiration for this work as well as providing crucial data concerning the Ogoni group. Prof. W. Chafe of the University of California, Berkeley is also to be thanked for encouraging me in my comparative work on Cross River in general, and Lower Cross in particular. Dr. L. Marchese and Dr. K. Demuth provided helpful suggestions, and financial support was furnished in part by the National Science Foundation. 
distinguish many of the languages to the west of an arc formed roughly by the Niger Delta, the Cross River basin, and the Niger-Benue confluence from those to the east. This arc in fact defines the area where the languages of the Cross River group are spoken, and, in many ways, the Cross River ${ }^{2}$ group represents the interface between the western and eastern Benue-Congo languages. In the area of phonology, while $-\mathrm{CVCV}^{3}$ roots predominate to the east and $-\mathrm{CV}$ roots predominate to the west, $-\mathrm{CVC},-\mathrm{CVV}$, and -CVVC roots typify the Cross River languages. While many Bantu pitch systems are clearly accentual and often have only two levels of contrastive tone as opposed to western Benue-Congo systems, where accentual phenomena play a more limited role and where three-level tonal systems are quite common, many Cross River languages exhibit very interesting and complex pitch systems in which basically two-level tone systems interact with accent or stress systems to establish conditions favorable to the phonemicization of a third level of contrastive tone. In the area of morphology, the nominal class/ concord systems of the Upper Cross languages once again represent a transition from the conservative systems of the east to the more innovative or simplified systems of western Benue-Congo. In fact, each subgroup of Cross River represents a macro-link in a very smooth chain of development from proto-Benue-Congotype systems with CV- prefixes, full class/gender distinctions, and numerous concord points to prefixless systems with no class/gender distinctions and pronominal subject-verb concord only.

1.2. Cross River languages used in this work. Several languages from each subgroup of Cross River have been singled out as sub-1inks or micro-1inks in the

${ }^{2}$ The Cross River languages are spoken by some sixty language communities found primarily in the Cross River and Rivers States of southeastern Nigeria. The definition of Benue-Congo used in this work will be that developed by the Benue-Congo Working Group of the West African Linguistic Society (1984) which includes the former Eastern Kwa subbranches of Yoruboid, Edoid, Nupoid, Idomoid, and Igboid, along with the "traditional" Benue-Congo subbranches, that is, Plateau, Jukunoid, Cross River, Bantoid, and Bantu.

${ }^{3}$ The following abbreviations are used in this work:

$$
\begin{aligned}
& \text { C - consonant } \\
& E \text { - east } \\
& \mathrm{N} \text { - sy1labic nasal } \\
& \mathrm{P} \text { - plural } \\
& \begin{array}{l}
\text { PBC - proto-Benue-Congo } \\
\mathrm{S}-\text { singular } \\
\mathrm{V}-\text { vowel } \\
\mathrm{W}-\text { west }
\end{array}
\end{aligned}
$$


above-described chain, typifying even finer increments along the continuum of class/concord systems evolution. Choice of language was in some cases dictated at least in part by availability of data. At least four languages were selected from each subgroup (except for Bendi) including the following:

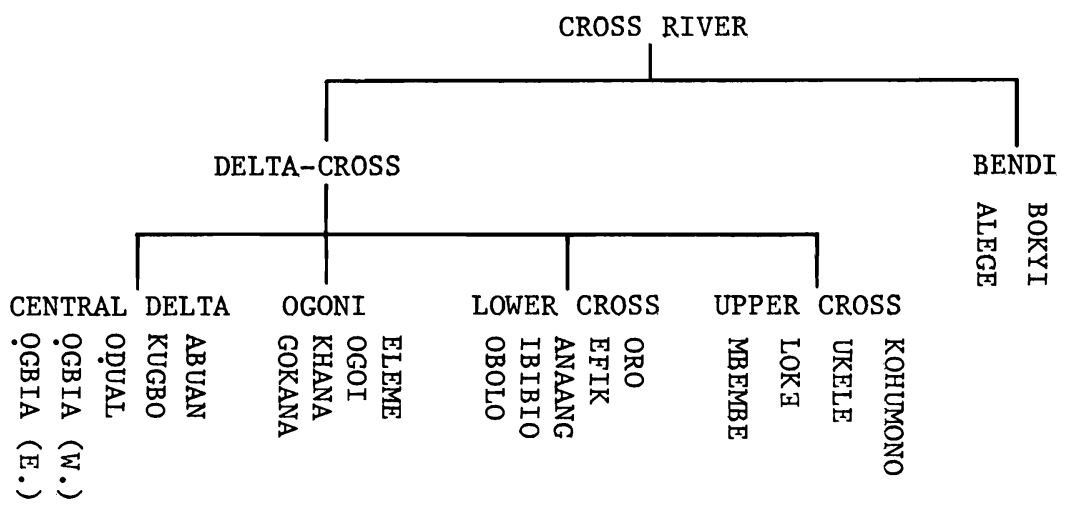

Table 1. Cross River languages used in this work

2. Morphophonology: Prefix Shape and Prefix Alternations

2.1. Upper Cross and Bendi: conservative systems. As shown in Table 2 on the following page, proto-Benue-Congo-type CV- prefixes have survived in Upper Cross languages, but to varying degrees, ranging from roughly $75 \%$ of the prefix inventory in Kohumono and Ukele to $55 \%$ in Lokə and only $13 \%$ in Mbembe. Kohumono seems to be the most conservative system, allowing only prefixes of the form Vbeside CV- prefixes, while the other languages allow N- prefixes, especially in the plural, which, if we accept De Wolf's [1971] reconstructions, must be innovations. The Bendi languages seem to exhibit a similar range of CV-prefix retention as in Upper Cross (from rough1y $80 \%$ of the prefix inventory in Bokyi to $10 \%$ in Alege). There are, however, key differences between the two groups, as we11. While Upper Cross makes widespread use of $\mathrm{N}$ - prefixation in the plural, the $\mathrm{N}$ - prefix is of relatively little importance in Bendi. In Bokyi (as well as in other Bendi languages?) there may be a tendency toward the incorporation of the reflexes of $\mathrm{PBC}{ }^{*} \mathrm{CV}$ - prefixes into roots and subsequent pre-prefixation of a vowel to the collapsed [proto-prefix + root] form (see the form for 'twen- 


'egg' 'tooth' 'tree' 'twenty'

PROTO-BENUE-CONGO

[De Wolf 1971]
S (Class 5) * i
$P$ (Class 6) *à-

(5) * $\mathrm{i}-$

(7) ${ }^{*} \mathrm{ki}-$

(6) *à-

(8) *bi-

(5) $* 1 \mathrm{i}-$

UPPER CROSS

Kohumono

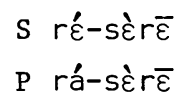

Ukele

S $|\bar{\varepsilon}-s: \bar{\varepsilon}| \bar{\varepsilon}$

$\mathrm{P}$ ?

S é-sê: nó

$\mathrm{P}$ ก̀-sê: ná

Mbembe

$$
S \text { é- } \int \hat{\imath}
$$$$
\mathrm{P} \hat{n}-\int \hat{\imath}
$$

BENDI

Bokyi

Alege

$$
\begin{aligned}
& \text { rè-tán } \\
& \text { rà-tán }
\end{aligned}
$$

| $\overline{-}-t: a ̀ \overline{:} \mid$ |ā-t:à: |

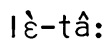

à-tâ:

غ̀-tá

à-tá

$$
\text { bù- } \int a ́ n
$$$$
\text { à- } \int a ́ n
$$

ó- $\int \bar{a} n$

é- $\int \bar{a} n$ hè-sē

bè-sē

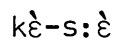

b

kè-tí

jè-tí

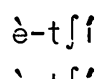

ǹ-t $\int \hat{i}$ rè-nù

$----$

1亏-।

$---$

lè-jáw

غ̇-ró $\beta$

---- 
occur only in plural forms and are often the only phonological material differentiating the plural form from the singular, where nouns typically consist of the original root and a V-prefix. The pre-prefix is invariably /A-/ (realized as $[a-]$ or $\left[a^{-}\right]$in harmony with the value for [ \pm WIDE (PHARYNX)] of the vowel(s) of the root. $/ A-/$ is also the most (the only?) productive nominal prefix, loan words being assigned only this prefix in Ogbia [Isuku1 1982].

2.3. Further developments in the Central Delta subgroup. As shown in Table 3 below, in Western Ogbia $\mathrm{PBC}{ }^{*} \mathrm{CV}$ - prefixes are of ten replaced by the suffix

PBC

'tooth (P)'

*à

UPPER CROSS

Kohumono

CENTRAL DELTA

Abuan

Kugbo

Oḍual

Ogbia

$\mathrm{x}=$ no cognate was found

Table 3. $\mathrm{PBC}{ }^{*} \mathrm{CV}$ - prefix incorporation into roots and pre-prefixation in Central Delta

/-za/ in the plural rather than being incorporated into roots. In most of the rest of the Central Delta languages $\mathrm{PBC}{ }^{*} \mathrm{CV}-$ prefixes are replaced by V- prefixes which exhibit only one generalized singular/plural alternation (V-/I-) and that only for some nouns, many $V$ - prefixes showing no alternation between singular and plural forms.

The net result of the above outlined processes is a [V prefix + root] structure for most Central Delta nouns, but with recoverable reflexes of $\mathrm{PBC}$ ${ }^{*} \mathrm{CV}$ - prefixes incorporated into many roots, especially in the plural. 
$\mathrm{PBC}$

\begin{tabular}{|c|c|c|}
\hline 'tree' & 'egg' & 'husband, man' \\
\hline${ }^{*} k i-$ & $* 1 i-$ & $*_{\mathrm{u}}-$ \\
\hline *bi- & *à- & *bà- \\
\hline
\end{tabular}

UPPER CROSS

Kohumono

$$
S \text { hè-s̄̄ }
$$

$r \dot{\varepsilon}-s \grave{\varepsilon} r \bar{\varepsilon}$

ò-rōm

$P$ bè-sē

rá-sغ̀r $\bar{\varepsilon}$

ßà-rōm

Ukele

$$
\begin{array}{ll}
\mathrm{S} & k \dot{\varepsilon}-s: \grave{\varepsilon} \\
\mathrm{P} & b \dot{\varepsilon}-s: \dot{\varepsilon}
\end{array}
$$

$|\bar{\varepsilon}-s: \bar{\varepsilon}| \bar{\varepsilon}$

wanwo-lam

?

bambe-Ian

BENDI

Bokyi

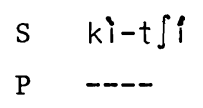

djî-cèé

á-cèé

\begin{tabular}{|c|c|c|c|c|}
\hline \multirow[t]{2}{*}{ Abuan } & $\mathrm{S}$ & ò-rén & è-yèlè & ò-lòm \\
\hline & $\mathrm{P}$ & i-rén & ว̀-rèyèlè rè-yèlè & ò-lòm \\
\hline \multirow[t]{2}{*}{ Kugbo } & $\mathrm{S}$ & ò-rèrén & à-gá & ò-wòl òm \\
\hline & $\mathrm{P}$ & i-rèrén & rà-gá & ò-wò lòm \\
\hline \multirow[t]{2}{*}{ Oḍua1 } & $\mathrm{S}$ & ò-rěn & j-gà & ò-1: òm \\
\hline & $\mathrm{P}$ & i-rĕn & i-gá & ə-bùrùlòm bùrù-lòm \\
\hline \multirow[t]{2}{*}{ E. Ọgbia } & $\mathrm{S}$ & ò-rèrén & à-gá & ò-w̃ùnòm \\
\hline & $\mathrm{P}$ & i-rèrén & à-gá & ò-w̃ùnòm \\
\hline \multirow[t]{2}{*}{ W. Ogbia } & $\mathrm{S}$ & ò-rén & à-ǵ́n & ò-w̃ùnòm \\
\hline & $\mathrm{P}$ & ì-rén & à-géń-zà & ò-w̃ùnòm \\
\hline
\end{tabular}

$\mathrm{x}$
$\mathrm{x}$

CENTRAL DELTA

Table 4. Gradual collapse of singular/plural distinctions in Central Delta

2.4. Lower Cross: proliferation of the $N$ - prefix. Plural nouns are distinguished from singular nouns in Oro and Efik only among the Lower Cross languages, and then only in a minority of cases (mainly nouns referring to humans in Efik). While incorporated prefixes are sometimes used for this purpose in these languages, the $\mathrm{N}$ - prefix is much more commonly used. The occurrence of the $\mathrm{N}$ - prefix in Lower Cross is by no means restricted to plural forms 
in Oro and Efik, however. In all Lower Cross languages, the $\mathrm{N}$ - prefix occurs quite frequently on nouns which do not vary in form from the singular to the plural. CV-prefixes are non-existent in Lower Cross.

2.5. Reduced vowel inventories in Lower Cross prefixes. Only nine of the ten phonemic vowels of Lokə (Upper Cross, see Runsewe [1982]) may occur in nominal class/concord prefixes, reflecting a general tendency among Benue-Congo languages which may play a significant part in the reduction of vowel inventories [Williamson 1982]. Via a process of merger and assimilation of prefix vowel quality to that of the following root, prefix vowel inventories have been significantly reduced in all Lower Cross languages. In Ibibio and Anaang, for example, roots containing -0 or -0 may only be preceded by $0-$ or $0^{-}$ prefixes, respectively. Subject concord prefixes on verbs harmonize with root vowels in all Lower Cross languages except Obolo.

2.6. Lower Cross: 1imited prefix 1oss. Prefix-1ess nouns occur in a11 Lower Cross languages, except 0ro. The proportion of nouns without a prefix is slightly higher in Obolo (from 5-10\%) than in Efik, Anaang, or Ibibio (less than 5\%) (see the plural form of 'woman' in Table 5 on the next page, for example). In Efik, some "prefix-1ess" nouns "regain" their prefixes when modified by (certain?) adjectives. Interestingly the quality of these "resurfacing" V- prefixes is not predictable and therefore must be included in the lexical specification of the noun.

EFIK [Cook and Ita 1967]:

$\begin{array}{ll}\text { [NOUN] } & \text { [ADJECTIVE-NOUN] } \\ \text { bjà 'yam' } & \text { á-kànì à-bjà 'old yam' } \\ \text { bùd 'shame' } & \text { à-kámbà ó-bùd 'great shame' } \\ \text { bjòn 'hunger' } & \text { à-kámbà ó-bjòn 'great hunger' }\end{array}$

In the Okorete (Eastern dialect of obolo as well as in the speech of children in that language, a syllabic nasal "prefix" bearing low tone occurs on nouns which are prefixless in the other dialects. 


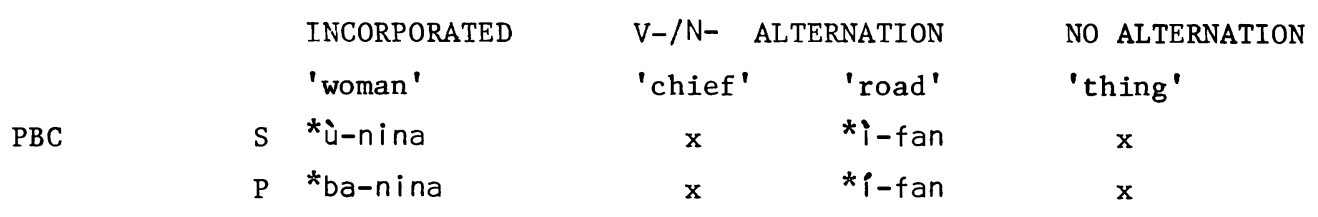

LOWER CROSS

\begin{tabular}{|c|c|c|c|c|c|}
\hline \multirow[t]{2}{*}{ Oro } & S & 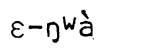 & ว́-f̄̄ & à-fàn & $\dot{N}-k p \hat{s}$ \\
\hline & $\mathrm{P}$ & $\grave{N}$-mà & $\dot{N}-f \bar{J} n$ & $\grave{N}$-fàn & ---- \\
\hline \multirow[t]{2}{*}{ Efik } & $S$ & $(\hat{N})-\eta^{w a ̂ n}$ & ว́-b̄̄n & à-fàn & $\hat{N}-k p o ́$ \\
\hline & $P$ & í-bân & N-bう̄̄ & ---- & ---- \\
\hline \multirow[t]{2}{*}{ Anaang } & S & N-ワwân & ว́-bう๊̄ & à-fàn & $\hat{N}-k p o ́$ \\
\hline & $\mathrm{P}$ & i-bàn & ---- & --- & ---- \\
\hline \multirow[t]{2}{*}{ Ibibio } & S & $\hat{A}-\eta^{W} \hat{a}: n$ & Á-bó:D & à-fàn & $\hat{N}-k p s ́$ \\
\hline & $\mathrm{P}$ & í-bâ: n & ---- & --- & ---- \\
\hline \multirow[t]{2}{*}{ Obolo } & S & gwân & ú-bว́: & à-fう̀n & $\hat{N}-k p o ́$ \\
\hline & $\mathrm{P}$ & í-bâ:n & ---- & ---- & --- \\
\hline
\end{tabular}

Table 5. Relics of singular/plural distinctions in Lower Cross

Examples: $\quad$ OBOLO

Western and Northern Dialects
Eastern Dialects
children's speech

$\begin{array}{ll}\text { 'oil palm' } & \text { 'children' } \\ \text { kô:k } & \text { bô:n } \\ \text { Ǹkô:k } & \grave{N} b \hat{s}: n \\ \text { Ǹkô:k } \sim \text { kô:k } & \grave{N} b \hat{s}: n \sim b \hat{s}: n\end{array}$

2.7. Ogoni: complete loss of prefixes. Among the Ogoni languages, Eleme stands out as the most conservative in terms of class/concord prefix retention. The Eleme system is in many ways similar to that of obolo (Lower Cross) in terms of the proportion of prefixless nouns it contains and in terms of the predominance of $\mathrm{V}$ - and $\mathrm{N}$ - prefixes in the language. Some important differences exist between Eleme and Obolo, however, which indicate that Eleme has actually gone further than obolo toward simplification of the PBC class/ concord system. Eleme as well as the rest of Ogoni (except for some isolated 
cases in Khana) differentiates itself from Obolo (and the rest of Cross River!) in that tone over prefixes is not contrastive (prefixes in the Ogoni languages either invariably bear low tone, as in Eleme and ogoi or copy their tone from the initial syllable of the following root, as in most Khana forms). While both $\mathrm{V}-$ and $\mathrm{N}$ - prefixes occur in Eleme, the proportion of $\mathrm{N}$ - to $\mathrm{V}-$ prefixes is much higher in Eleme than in obolo. Finally, only three contrastive vowel qualities $(/ a-/, / E-/$ and $/ 0-/$ ) are found in Eleme prefixes, showing an even greater tendency toward merger and harmonization than that noted above for Lower Cross (see section 2.5). In less conservative Ogoi, all V- prefixes are eliminated and only $\mathrm{N}$ - prefixes persist (usually on nouns which also take the $\mathrm{N}$ - prefix in Eleme as we11). In Khana and Gokana class/concord prefixes are virtually non-existent. In all ogoni languages (including Gokana), however, some independent pronouns bear an initial vowel (prefix) which in some persons agrees in quality with the corresponding dependent subject pronoun (subject concord prefix relic; see section 3.2).

\begin{tabular}{|c|c|c|}
\hline & 'tooth' & 'tree' \\
\hline PBC & *li-/a- $(5 / 6)$ & ${ }^{*} \mathrm{ki}-/ \mathrm{bi}-(7 / 8)$ \\
\hline
\end{tabular}

UPPER CROSS

Kohumono

$\begin{array}{lll}S & \text { rè-tán } & \text { hè-sē } \\ P & \text { rà-táǹ } & \text { bè-sēe }\end{array}$

----

i-tòtóı ( $\mathrm{P}$ only)

LOWER CROSS

Efik

$S, P$ é-dèt

è-tó

$\dot{N}-t o ́ n$

OGONI

E1eme

S,P à-dá:

dá:

Ogoi

Khana

Gokana dá:

dá: è-té

té

té

té
$\grave{\mathrm{N}}-\mathrm{t} \tilde{\mathrm{O}}$

$\grave{N}-+\stackrel{\tilde{J}}{ }$

tớ

$(-r u ̀)$

Table 6. Class/concord prefix loss in Ogoni 


\section{Concordial Agreement}

3.1. Upper Cross, Bendi, and Central Delta: conservative systems. In the Upper Cross, Bendi, and Central Delta languages, many languages (if not most) have retained most of the loci of concordial agreement which are traceable to proto-Benue-Congo, including pronominal, subject-verb, adjectival, determiner, demonstrative, and numeral concord points. Numeral concord is often a relic, usually holding only in the case of a few of the lowest numerals.

3.2. Lower Cross and Ogoni: relics of concord only. In the Lower Cross and the Ogoni languages, only a few relics of concordial agreement systems survive. In most of Lower Cross and Ogoni the only type of concord exhibited is limited to the agreement in some persons between the initial vowel (prefix) of the independent subject pronoun and the dependent verbal subject prefix.

OBOLO

$\begin{array}{llll}\text { ò-mô } & \frac{o}{3}- & \text { nù } & \text { 'he/she came' } \\ \text { he/she } & 3 \text { d s dep. PN come } & \\ \text { è-mâ } & \text { é } & \text { nù } & \text { 'they came' } \\ \text { they } & \text { 3rd P dep. PN } & & \end{array}$

In Oro and in Efik, however, noun-adjective concord occurs sporadically. In Oro, adjectives in some cases show singular/plural distinctions not normally marked on the nouns which they modify (this may be due to the fact that such adjectives are derived from verbs and their prefixes alternate according to patterns typical of dependent subject pronouns, as in the Obolo example just given).

$\begin{array}{ll}\text { EFIK [Cook and Ita 1967] } & \text { 'old doctor' } \\ \begin{array}{l}\text { à-káni á-bjà-ibj̀k } \\ \text { old doctor }\end{array} & \text { 'old doctors' } \\ \begin{array}{l}\text { Ǹ-káni Ń-bjà-ibj̀k } \\ \text { ORO [Kuperus 1978] }\end{array} & \\ \begin{array}{l}\text { È-fjé á-bà } \\ \text { white dog }\end{array} & \text { 'white dog' } \\ \text { i-fjé á-bà } & \text { 'white dogs' }\end{array}$


4. Class/Gender Membership

4.1. Upper Cross, Bendi, and Centra1 Delta: retention of PBC class/gender distinctions. As shown in Tables 2-4, the distinctions between the major classes and genders of proto-Benue-Congo are maintained in such Upper Cross and Bendi languages as Kohumono and Bokyi, but in languages such as Mbembe and Alege as well as in the Central Delta languages, there is a tendency toward the merger of singular classes into a single class marked by $/ 0-/$ and the merger of plural classes into a single class marked by $/ \mathrm{l} /$, /e-/, or /N-/ (see sections 2.4 and 2.5 above).

4.2. Lower Cross and Ogoni: complete loss of gender distinctions, partial loss of class distinctions. As shown in Tables 5 and 6 , relics of plural prefixes $/ \mathrm{i}-/$ or $/ \mathrm{N}-/$ occur sporadically in Lower Cross, while no plural prefixes at all are retained in Ogoni (except for one or two isolated cases in Eleme). ${ }^{4}$ Only in the case of some of the reflexes of nouns belonging to the "human" (* $1 / 2)$ gender of proto-Benue-Congo are singular/plural distinctions maintained throughout Lower Cross, via the incorporation of PBC prefixes into roots and subsequent pre-prefixation (see 'woman' in Table 5). Despite the high degree of class merger, the widespread loss of singular/plural distinctions (and the concomitant proliferation of the $\mathrm{N}$ - prefix across all classes) as well as the extensive reharmonization of prefix vowels to stem vowels which typify many Cross River (especially Lower Cross and Ogon 1 ) 1anguages, a few prefixes can still be associated (albeit rather loosely) throughout the subbranch with the semantic categories corresponding to one or another of the noun classes of PBC. A case in point is the "large animal" gender (PBC 9/10 ${ }^{*} i-l^{*} i-$ ) whose reflexes still show regular patterning throughout Cross River. (see Table 7 on the following page).

${ }^{4}$ My thanks to Kay Williamson for bringing this to my attention. 


\begin{tabular}{|c|c|c|}
\hline PBC $9 / 10\left({ }^{*} i-/ i-\right)$ & $\begin{array}{c}\text { 'animal, meat' } \\
(\mathrm{S} / \mathrm{P})\end{array}$ & $\begin{array}{c}\text { '1eopard' } \\
(\mathrm{S} / \mathrm{P})\end{array}$ \\
\hline
\end{tabular}

UPPER CROSS

Kohumono

Ukele

Lokə

Mbembe

BENDI

Bokyi

Alege

CENTRAL DELTA

Abuan

Kugbo

Odual

E. Ogbia

W. Ogbia

LOWER CROSS

Oro

Efik

Anaang

Ibibio

obolo

OGONI

Eleme

Ogoi

Khana

Gokana

$$
\begin{aligned}
& \text { غ̇-zغ̀n/i-zغ̀n } \\
& \bar{\varepsilon}-s \bar{\varepsilon}: n / T-s \bar{\varepsilon}: n
\end{aligned}
$$

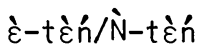

$$
\begin{aligned}
& \text { è-tèn/Ǹ-tèn }
\end{aligned}
$$

è-ràm

í-njã

ı-kpj̀n

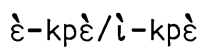

$\mathrm{N}-\mathrm{b} \varepsilon$

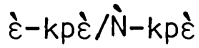

è-t $\int \grave{e} / \grave{N}-t \int \grave{e}$

X

$\mathrm{x}$

$\mathrm{x}$

è-wèl/

è-vèl/i-vèl

è-wèl

è-wèl/î-wèl $\varepsilon$-nam/l-nam

Ł̀-nàm/ìnàm

غ̀-nàm/i-nàm

غ̀-n: àm

(à-bíri)

(à-bíri)
$---$

é-kpè

é-kpè

é-kpê

é-gbè

Ǹ-kpê :

$---$

kúè

kp $\tilde{\varepsilon}$ 6-fú

é-bót

é-bót

é-bót

é-bót

Table 7. Reflexes of PBC "large animal" gender (9/10) in Cross River 
5. An Implicational Scale for Class/Concord Systems Simplification in BenueCongo?

Table 8 on the following page represents a summary of the developments outlined in the preceding sections of this work. At least four patterns exhibited by the data deserve further mention here because of their possible significance for the study of the evolution of class/concord systems throughout BenueCongo (and perhaps Niger-Congo as well; see Demuth et al. [forthcoming]).

5.1. Class/gender distinctions: patterns of simplification. The Cross River data suggests the following, all other factors being equal:

(1) Class/gender distinctions are lost for [-animate] nouns before [+animate] nouns (see Table 7).

(2) Class/gender distinctions are lost for [-human] nouns before [+human] nouns.

(3) Gender distinctions are lost before class distinctions.

5.2. Concord points: hierarchy of persistence. All other factors being equal, the evidence from Cross River indicates the following hierarchy of persistence can be set up with agreement patterns least likely to be lost at the top and those most likely to be lost at the bottom:

\section{PERSISTENCE HIERARCHY}

1) Strongest: subject-verb concord

2) Strong: adjective-noun concord

3) Weak: other concord points, especially numeral-noun concord

5.3. Prefix shape: template-type processing and areal phenomena. The patterns of simplification of prefix shape outlined above for the Cross River languages suggest that prefix shape could be influenced to a large extent by areally-determined templates. In other words, the canonical form of class/ concord affixes for each subgroup reflects a generalized areal pattern of prototypical prefix shapes. CV- prefixes are not only typical of many Upper Cross and Bendi languages, but also of the neighboring Bantu languages. Nprefixes are found throughout Western Benue-Congo as well as in some Western Bantu languages and, therefore, their widespread occurrence in the subgroups of Cross River which border on areas where these languages are spoken may not 


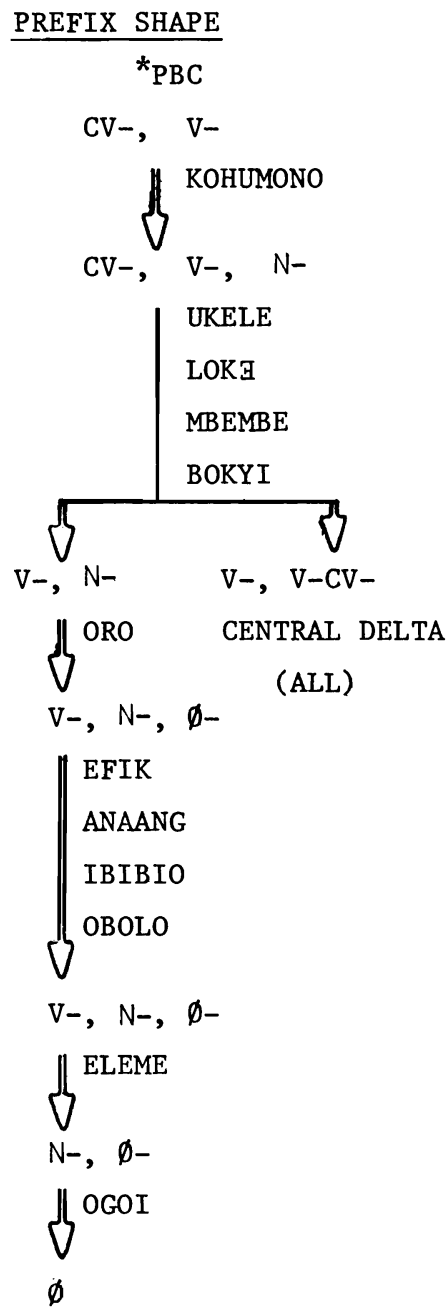

KHANA

GOKANA $\frac{\text { CONCORD POINTS }}{{ }^{*} \text { PBC }}$

FULL CONCORD

$\| \begin{aligned} & \text { LOKA } \\ & \text { BOKYI? }\end{aligned}$

FULL CONCORD

EXCEPT

NUMERALS

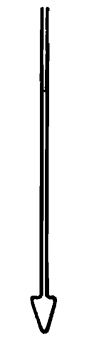

KOHUMONO

UKELE

MBEMBE

ALEGE?

CENTRAL DELTA

(ALL?)

RELICS OF

ADJECTIVE AND

SUBJECT-VERB

CONCORD ONLY

$\oiint_{\text {ORO }}^{\text {EFIK }}$

SUBJECT-VERB

CONCORD ONLY

ANAANG

IBIBIO

OBOLO

OGONI $\frac{\text { NOUN CLASSES }}{{ }^{*} \mathrm{PBC}}$

FULL CLASS/GENDER

DISTINCTIONS

$\| \begin{gathered}\text { UPPER CROSS } \\ \text { (ALL?) } \\ \text { BOKYI }\end{gathered}$

PARTIAL MERGER OF [-HUMAN]

NOUNS TO 0-/I-

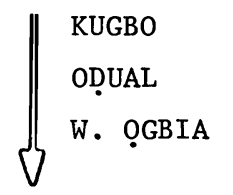

FULL MERGER

OF [-HUMAN]

NOUNS TO $0-/ I_{-}$

$\| \begin{aligned} & \text { ABUAN } \\ & \text { E. OQGBIA }\end{aligned}$

RELICS FOR BOTH

[ \pm HUMAN] NOUNS<smiles>[R9]OC1C=C[C]1C</smiles>

RELICS FOR [+HUMAN]

NOUNS ONLY

$\| \begin{aligned} & \text { EFIK } \\ & \text { ANAANG } \\ & \text { IBIBIO } \\ & \text { OBOLO }\end{aligned}$

NO DISTINCTIONS

OGONI (ALL)

Table 8. Reflexes of the proto-Benue-Congo nominal class/concord system in Cross River 
be as surprising as it would seem at first glance. The fact that the Ogoni and Lower Cross languages are spoken in close proximity to the prefixless Ijo languages may in part explain the occurrence of prefixless nouns in their inventories. The suffixation patterns found in $\mathrm{W}$. Ogbia may also correspond to a generalized tendency toward suffixation in neighboring Ijo languages. It should be stressed here that, due to the high frequency of intermarriage between speakers of different but geographically contiguous languages, many children of speech communities where Cross River languages predominate are actual1y raised by a parent who is not a native speaker of a Cross River language.

5.4. Primacy of concord over class: an argument for prosodic processing. As indicated in Table 8, morphological concord systems persist after both phonological marking of prefixes and morphosemantic class/gender distinctions are virtually reduced to zero in Gokana. This surprising fact would seem to indicate that class/concord systems are processed primarily as prosodies over entire phrases rather than as nomino-centric prefix copying systems. This argument is given further support by the "resurfacing" prefixes described for Efik in section 2.7 as well as by experimental language acquisition data for some Bantu languages [Demuth et a1, forthcoming]. 


\section{REFERENCES}

Cook, T. L. and K. E. Ita. 1967. The pronuncation of Efik for Speakers of English. Bloomington: Indiana University African Studies Program.

Demuth, K., N. Faraclas, and L. Marchese. forthcoming. "Noun classes and concordial agreement systems in first language acquisition and historical change." In C. Craig (ed.), Noun Classification and Categorization. Philadelphia: Benjamins, N.A.

Isuku1, C. 1982. "Nomina1 prefixes in Ọgbia (Kolo dialect)." Paper presented to the 3rd annual meeting of the Linguistic Association of Nigeria, University of Ilorin, Nigeria, August 18-22, 1982.

Kuperus, J. 1978. "Esquisse du système verbal de 1'oro du Nigéria." Thèse de IIIe cycle, Sorbonne, Paris V.

Runsewe, 0. I. 1982. "Vowel harmony in Lokə." Paper presented to the 3rd annual meeting of the Linguistic Association of Nigeria, University of Ilorin, Nigeria, August 18-22, 1982.

Williamson, K. 1982. "Vowel merger in harmony languages." Paper presented to the-3rd annual meeting of the Linguistic Association of Nigeria, University of Ilorin, Nigeria, August 18-22, 1982.

Williamson, K. forthcoming. "How to become a Kwa language." In A. Melby and A. Makkai (eds.), Essays in honor of Reuben S. Wells. Jupiter Press.

Wolf, P. de. 1971. The Noun Class System of Proto-Benue-Congo. Paris, the Hague: Mouton. 